\title{
PRODUCT PLACEMENT - CITY PLACEMENT AS A FORM OF URBAN SPACE PROMOTION
}

The paper presents product placement and especially city placement as one of the urban space promotion directly linked with the environment communication.

Product placement, and thus places in film and television have already been widely known. An increasing number of local governments are interested in this form of advertising for the city and spend more money for this kind of promotion. Not many local governments check if the traditional advertising or city placement in films or other television productions is effective. It is caused by high cost of marketing research.

City placement is connected with promotion and exactly with advertising. It is the chance for alternative form of communicating with the environment. The urban space of a community in the following paper is treated as the product which can be sold by a community because everything which has value to the consumer can be sold. Main objectives of this kind of advertising can be for example attracting investors, increasing satisfaction of citizens, attracting students, specialists to the city and change in opinions about the city among the society. City placement is the creating of the image of the city.

In the paper the examples of such presenting the community have been showed.

Keywords: marketing, territorial marketing, communication, promotion, advertising, product placement, city placement.

\section{TERRITORIAL MARKETING AS THE CONCEPT OF MANAGEMENT OF THE COMMUNITY}

The concept of management of a community should be based on the achievements of science of business management and entrepreneurial thinking should be the basis of decisions taken in the economic self-government institutions. This is the basic condition for their development. Such an approach assumes, however, that the management of a city, village, region under the dominance of market relations must take into account the interests of customers - citizens - as the main reference group. Territorial marketing is also directed to an external audience for example potential investors. The whole management process should be oriented on customers for the goods and utilities, their needs and de-

\footnotetext{
${ }^{1}$ Izabella Sowier-Kasprzyk, PhD, Eng., Wydział Zarządzania, Politechnika Częstochowska, Częstochowa, Al. Armii Krajowej 19 B, 42-200 Częstochowa, e-mail: ibby@ interia.pl, tel.: +48343250424

${ }^{2}$ Adam Ujma, PhD, Eng., Wydział Budownictwa, Politechnika Częstochowska, Częstochowa, ul. Akademicka

3, 42-200 Częstochowa, e-mail: aujma@ bud.pcz.czest.pl, tel.: +48 343250914
} 
sires. In the activity of territorial units should be oriented on the needs of local and regional appropriate to adopt by the authorities a marketing point of view ${ }^{3}$. $\mathrm{ty}^{4}$ :

There are the following assumptions in the marketing management of the communi-

- settlement unit of a certain shape of space-administration is a habitat in the community whose needs and desires are the main guideline for the governing bodies of its resources,

- satisfying the needs and desires of the inhabitants of a settlement unit is largely dependent on its links with other areas in the form of flows of goods and cash, technology, manpower and information,

- the needs and desires of the inhabitants change - particularly in the long term- and therefore they should be monitored by a specialized marketing research,

- the process of meeting current and future needs and desires of the inhabitants requires a rational held before the unit settlement tangible and intangible assets, in property and financial, movable and immovable, tangible and rotary own and strangers,

- satisfying the needs and desires of the individual settlement as a whole cannot be inconsistent with meeting the needs of individual residents or smaller groups, but on the contrary - meeting the needs of "minorities" cannot be in conflict with the desire to satisfy them by the whole community,

- settlement unit is "self-government" or "self-managing", it means that the management body is operated on behalf of inhabitants, comes from the people and acts on their behalf and in their interest, so it can not be a conflict of interests between the government and citizens,

- meeting the needs and desires of individuals and social groups leads to improved material conditions of their lives, as well as spiritual development, while satisfaction and the development of individuals, this corresponds to the popular statement "rich residents is a rich municipality or region" and "rich municipality or region is also rich residents".

Marketing to the inside audience stimulate the desired behaviour of residents and other groups located in the spatial unit. Goals that can be achieved through these actions include $^{5}$ :

- knowledge of current needs and desires of residents in municipal services provided by local authorities,

- ensuring favourable conditions for the use of public services by citizens and local organizations and groups,

- anticipate changes in preferences and behaviour of local players regarding the use of public goods and services,

- adding value to offer municipal addressed to the local community,

- improve the quality of local administration,

- recognize the level of commitment of local residents and businesses to the settlement unit,

\footnotetext{
${ }^{3}$ A. Szromnik, Marketing terytorialny. Miasto i region na rynku, Oficyna Wolters Kluwer business, Warszawa 2007, p. 11.

${ }^{4}$ Ibidem, p. 17.

${ }^{5}$ A. Szromnik, Marketing terytorialny - koncepcja ogólna i doświadczenia praktyczne, [in:] Marketing terytorialny, ed. T. Markowski, Komitet przestrzennego Zagospodarowania Kraju PAN, Warszawa 2006, p. 36, 41-42.
} 
- establishing efficient and effective channels of communication with the local authorities,

- determine the degree of social acceptance and social policies - economic - selfgoverning bodies,

- understanding of determinants of individual entrepreneurship in the settlement unit.

- raising the level of satisfaction of individuals and social groups of living conditions, work, rest and development of existing in a given territorial unit.

The main objective of territorial marketing is to influence opinions, attitudes and behaviors of internal and external groups interested customers through the development of appropriate set of measures and instruments to stimulate relations interchangeable. Thus the objective formulated marketing efforts spatial-administrative units indicates the important features of their undertakings, such as the formation of opinions, attitudes and customer behavior consistent with the interests of the city, village or region. This is illustrated in figure 1.

The main operational goal of territorial marketing in the case of external groups will "ascertain the reasons for the procedure, criteria and preferences, which are guided by assessing the attractiveness of a settlement unit by choosing sites and expressing satisfaction with the conditions created by the city, village or region. For the purposes oriented on the outside it may include the development of a comprehensive investment offer, tourism, culture and trade. It is important to communicate effectively with stakeholders or the formation of personality, identity and attractive image of the area"6.

In the literature there are many definitions of territorial marketing. Often the differences are due to differences in the interpretation of the marketing. If marketing is "a specific way of thinking about the company's success in modern business, it means that (...) territorial marketing is a philosophy to attain its objectives by settlement units in competition for limited resources, has a foundation in the belief that proper orientation on customer-partners have a decisive impact on its results"

\footnotetext{
${ }^{6}$ A. Szromnik, Marketing terytorialny. Miasto..., p. 24.

${ }^{7}$ Ibidem, p. 16.
} 
Fig. 1. Interactions and interchangeable relationships in territorial marketing
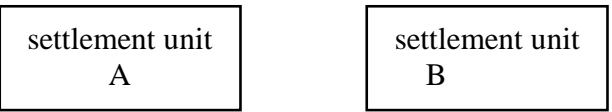

Correction of

marketing

activity

\section{Impact - offer Changes (goods, ser-}

vices, infor-

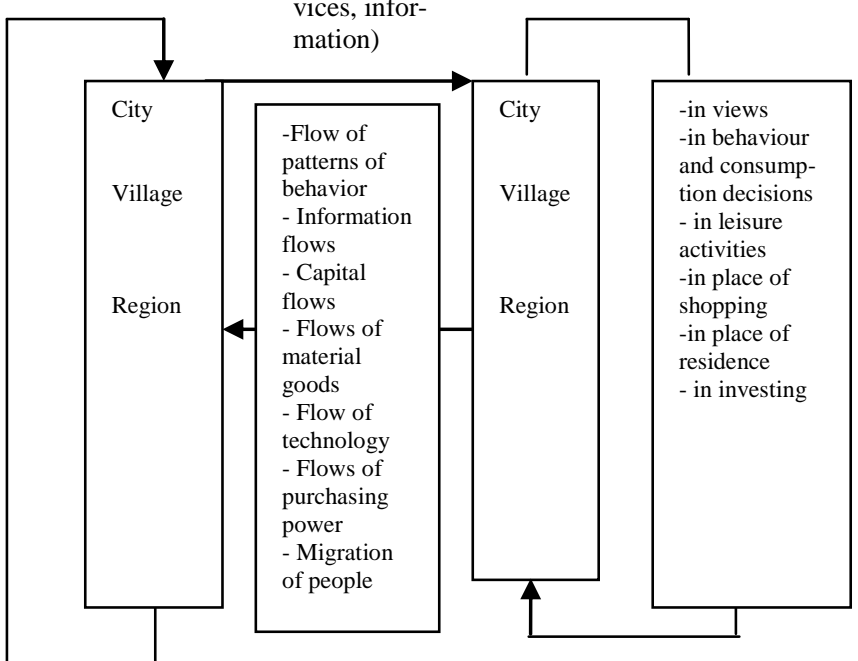

Source: own elaboration on the base of: A.Szromnik, Marketing terytorialny. Miasto i region na rynku, Oficyna Wolters Kluwer business, Warszawa 2007, p. 22.

Territorial Marketing can also be defined as "market management concept of a unit settlement - as management aimed at satisfying the needs and desires of citizens ${ }^{8}$." Territorial marketing is a "set of coordinated activities of local, regional and national efforts to create a process of exchange and interaction by identifying, shaping and meeting the needs and desires of buyers 9. "In contrast, by Markowski it is a "market-oriented management of the city (municipality) or the region concept by the authorities local government and its partners in order to meet current and future needs of users (clients), internal and external. The economic essence of marketing the city is manifested in strengthening its economic base and greater economic income ${ }^{10 "}$.

According to H. Meffert "city marketing includes analysis, planning and control programs whose aim is to achieve the desired exchange processes with selected markets or groups of customers". Although this definition refers to the marketing of the city it can also be adapted to the needs of territorial marketing (ie. on other areas, and not only settlement units such as cities). According to Basdereffa "territorial marketing encompasses

\footnotetext{
${ }^{8}$ Ibidem, p. 16-17

${ }^{9}$ A. Szromnik, Marketing komunalny. Rynkowa koncepcja zarzadzania gmina, „Samorząd Terytorialny” 1996/3.

${ }^{10}$ T. Markowski, Marketing Miasta, [in:] Marketing terytorialny, ed. T. Markowski, Komitet Przestrzennego Zagospodarowania Kraju PAN, Warszawa 2002, p. 108.
} 
all the strategic approaches and technical, that are used by organizations (associations, individuals, public institutions and enterprises) in order to gain new resources and improve the efficiency and quality of the project-oriented to meet the specific needs of the public, while maintaining the principles of ethics leading to fill a specific mission". V. Girard interprets territorial marketing in the following way: "territorial marketing includes a variety of techniques and measures used by local communities and organizations in the process of projecting planning economic development, tourism, urban, social, cultural or nature of identity project (...) to analyze the territorial mix needs analysis reported or hidden individuals or organizations (existing and potential) is an element of support ${ }^{11}$.

\section{PRODUCT IN THE TERRITORIAL MARKETING MIX}

Product in marketing approach may be all that buyers can obtain in the market. According to Kotler "A product is anything that can be offered to a market for attention, acquisition, or use, or something that can satisfy a need or want. Therefore, a product can be a physical good, a service, a retail store, a person, an organization, a place or even an idea. Products are the means to an end wherein the end is the satisfaction of customer needs or wants ${ }^{12}$ ". A product is also a landscape recreational or municipal area, which also should be encouraged to attract tourists. Tourists appearing in a given area involve any financial means, and thus followed the economic development of the municipality and the residents find employment in the tourism sector. It is called a tourist product. Tourism products are all goods and services produced and purchased in connection with travel outside the domicile both before the trip, during and during tourist stay outside the place of permanent residence ${ }^{13}$. Offered tourist product of municipality must be supported by marketing activities. Even the attractive tourist region can be unnoticed if it is not presented in a professional manner ${ }^{14}$.

The marketing strategy is based on marketing mix, consisting of several parts. A typical structure of the marketing mix consists of four components (4P): product, price, place (distribution) and promotion and was introduced by J. McCarthy. In services, the fifth, seventh or eighth element has been added. The seventh elements mixture consists of product, price, distribution, promotion, people, processes and customer service ${ }^{15}$. All these elements are equally important.

Municipal authorities must first create a suitable tourist product, expose it, fix its price, forms of distribution, as well as to inform potential customers about the existence of the product, or carry out a promotional campaign.

In marketing, we are talking about territorial marketing mix units. V. Girard proposes to consider the marketing mix from two perspectives ${ }^{16}$ :

- as an organizational mix referring to the local community and the surrounding organization;

\footnotetext{
${ }^{11}$ Ibidem, p. 18-19.

${ }^{12} \mathrm{Ph}$. Kotler, Analiza, planowanie, wdrażanie i kontrola, Warszawa 1994, p. 400.

${ }^{13}$ Przedsiębiorstwo Turystyczne. Ujecie statyczne i dynamiczne, ed. G. Gołembski, Warszawa 2007, p. 29.

${ }^{14}$ Organizacja imprez sportowych, ed. B. Ryba, Polska Korporacja Menedżerów Sportu, Warszawa 1998, p. 47.

${ }^{15}$ A. Pabian, Promocja. Nowoczesne środki i formy, Warszawa 2008, p. 20.

${ }^{16}$ Marketing terytorialny: strategiczne wyzwania dla miast i regionów, ed. T. Domański, Uniwersytet Łódzki, Łódź 1997.
} 
- territorial mix referring to the territory.

Territorial marketing mix should always take into account ${ }^{17}$ :

- territorial offer characterized by fixed and variable characteristics of the territory, expressing its organic parameters (history, culture, internal organization), economic, geographical and symbolic;

- conditions of the offer made available to interested groups and institutions, which are the specific costs of using them, participation, residence or consumption of the product units;

- ways and circumstances of the transfer of territorial product specifying the place, time, procedures and technical conditions of service to the public or the provision of material resources;

- forms, means and techniques to communicate subdivision with the environment, related to the shaping of its marketing image.

Sector approaches, separately treating tourism marketing, business or sports, are closer to the general concept set of marketing tools.

\section{PROMOTION OF URBAN SPACE - PRODUCT PLACEMENT AND CITY PLACEMENT}

Promotion is a form of social communication in the vitally important area of meeting the needs of material and intellectual products of human ingenuity, entrepreneurship, activity and effectiveness. It is a way to communicate with potential buyers of goods and services to influence their attitudes and behavior on the market. Moreover, the idea is to gain appropriately large group of tourists or convince the relevant group of people that it is worth to visit and stay longer in the municipality attractive for tourists. From a marketing point of view the overriding goal of promotion is to conclude with a client a specific transaction ${ }^{18}$

A comprehensive process of communication with the environment called the promotion mix consists of the following elements: advertising, sales promotion, public relations, personal selling, direct marketing ${ }^{19}$. For effective communication it is crucial to use suitable proportions of the individual elements, because "promotion is the knowledge and the art of choosing the right composition of the promotional mix ${ }^{20}$.

The modern and most desirable procedure involves the simultaneous use of all five instruments of promotion mix, i.e. advertising, direct marketing, sales promotion, public relations and personal selling. Such action is defined as an integrated promotion (mix) or integrated marketing communications. The main advantage of integrated communication with the environment is reaching out with information about the company, its products and activities to a much larger number of potential customers than is the case with the selective application of the individual components of the promotion mix. Consumers are in fact varying degrees susceptible to the influence of these elements. Some people do not like advertising, while eager to use shares as part of sales promotion. Other very negatively refer to visits by

\footnotetext{
${ }^{17}$ A. Szromnik, Marketing terytorialny. Miasto..., p. 77.

${ }^{18}$ Organizacja imprez..., p. 50.

${ }^{19}$ J. Klisiński, Podstawy marketingu, Częstochowa 2001, p. 97-98

${ }^{20}$ T. Sztucki, Promocja. Reklama. Aktywizacja sprzedaży. Sztuka pozyskiwania nabywców, Agencja Wydawnicza Placet, Warszawa 1995, p. 19
} 
salesmen (a form of personal sales), but eager to make purchases through catalogs and are susceptible to the influence of advertising. Thus the entrepreneur, using e.g. only advertising, reaches only to those customers who are subject to its influence. Meanwhile, thanks to the extension of instruments market impact of the remaining components of the promotion mix will grow much media audience interested in his offer, including not even those who cannot tolerate ads, but are prone to other kinds of action ${ }^{21}$.

Promotional activities therefore require an integrated used forms of influencing on consumers. Promoting connected with integrated management followed by levels of integration allow you to specify what to integrate, how to integrate tools and promotional activities. Integration in the promotion can be divided into two parts. The first is the integration of elements of the promotional mix and the other is the integration of activities in the phase of preparation and implementation of promotional projects. Both integrations should be linked. ${ }^{22}$.

In the case of municipalities integral part of the integrated promotional activities of the municipality is to create communication that allows two-way communication between stewards and residents, but the most common messages are one-sided, centered only around the activities carried out by the municipality. Local governments increasingly see the need and necessity of communication with different groups of recipients of their business. It should be noted, however, that this communication, often takes the form of unilateral messages sent to potential constituents ${ }^{23}$.

In today's market conditions, the possibilities of action of companies and organizations are the local authorities forming policies and strategies conducive to their development ${ }^{24}$.

As already mentioned promotion is a marketing communication that is associated with the transfer from the sender to the recipient in terms of buying and selling. The transmitted information is intended to raise awareness, encouragement and reminders. ${ }^{25}$.

It should also be noted that the shaping of promotion in the region should be based on several assumptions ${ }^{26}$ :

- the basis for effective promotion of the region is to build a clear, based on clearly formulated rules and division of competencies, organizational system;

- rapid development of marketing and processes shaping the market make the promotion a specialized field of knowledge, requiring appropriate staff and the continuous adjustment of previously developed solutions for change. The specificity of tourism is based on meeting the needs of discerning customers who usually avoid arrivals in place of the unknown, and therefore the information addressed to him must be comprehensive and precise orientation;

\footnotetext{
${ }^{21}$ A. Knapik, Składniki promocji mix oraz ich integracja, [in:] Środki i formy marketingowego oddziaływania na konsumentów, ed. A. Pabian, Częstochowa 2008, p. 154.

${ }^{22}$ A. Pabian, op. cit., p. 11-12.

${ }^{23}$ Więcej, np. analiza działań promocyjnych Częstochowy: K. Łazorko, Wybrane aspekty komunikacji samorzadu terytorialnego z otoczeniem, "Zeszyty Naukowe Uniwersytetu Szczecińskiego" 2007/12, p. 33-39.

${ }^{24}$ E. Chrzan, A. Widawska-Stanisz, Ponadregionalne znaczenie promocji zakładów przetwórstwa owocowowarzywnego z Zielonego Wierzcholka Ślaska, [in:] Wybrane aspekty rozwoju regionalnego Polski poludniowej, ed. W. Stasiewicz, P. Ucieklak-Jeż, Częstochowa 2008, p. 40-41.

${ }^{25}$ Promocja i kreowanie turystycznego wizerunku Polski..., p. 77.

${ }^{26}$ Ibidem, s. $77-83$.
} 
- tourist attraction of the region, which does not constitute a tourist product stops to be competitive. The term product should be understood as the demand. The customer expects a lot of information as to price, quality services, attractions, access to the Internet. That is why it is extremely important that the offer is understandable and comprehensive. This helps to achieve a stable organizational system based on the action of local and regional tourism organizations. They are formed of local governments, social organizations operating in the area, and others involved in tourism. The idea behind is effective tourism promotion of the area;

- for the promoting tourism in the region it is necessary to monitor the tourism market, taking into account both supply and demand. It gives the ability for proper managing the promotion, including planning, organizing and control.

- professional approach to tourism promotion must be based on knowledge, welleducated staff and the possibility of continuing education. Ignorance of market mechanisms and policy analysis, lack of knowledge of planning promotion, and even incompetent use of terminology marketing can lead to a loss of competitiveness of tourism in the region. With the rapid progress of marketing, due to the high dynamics of the market, it is necessary to introduce a system of training for staff dealing with the promotion of tourism.

Appropriate use of a set of instruments and marketing techniques in the management of promotion of the region became the basis for the development of tourism in many countries and regions. For using marketing it forces increasing competition. In the current market situation it is enough to have something and want to show it, but it's something you should be able to expose and exploit ${ }^{27}$.

In summary, therefore, the above considerations, the best issue of promotion of attractions regions and the benefits it can bring to tourism budgets of municipalities are the words of Gordon: tourism is a contemporary path of prosperity. Those win who take care of its development quickly, wisely and consistently. Currently, you should look for unconventional forms of promotion to attract consumers' attention to tourism products. Moreover, the consumer seems to be bored with traditional forms of advertising. Therefore, the optimal form of promotion of municipalities is product placement.

The following figure shows the relationship of product placement and city placement and marketing.

Product placement is a term associated with marketing and more specifically with the promotion, which was mentioned above as one of the element of the marketing mix. Product placement is a way of promoting by placing a product or a situation that presents a specific pattern of behavior (mostly consumer) in the movie, a play, a television program or other audiovisual media or printed material product ${ }^{28}$.

Currently product placement has become quite a popular form of advertising products in media with particular emphasis on television. City placement is a specific type of product placement, which is a form of promotion of a city by placing the related content in the film, television series, television program, radio, computer game etc., without checking that this is the promotional material ${ }^{29}$. Connections of product placement-city placement with marketing have been presented in figure 2 .

\footnotetext{
${ }^{27}$ Ibidem, p. 84.

${ }^{28}$ A. Czarnecki, Product placement. Niekonwencjonalny sposób promocji, Warszawa 2003, p. 22.

${ }^{29} \mathrm{http}: / /$ nowewyrazy.uw.edu.pl/haslo/city-placement.html?pdf $=1$.
} 
Fig. 2. Connections of product placement-city placement with marketing

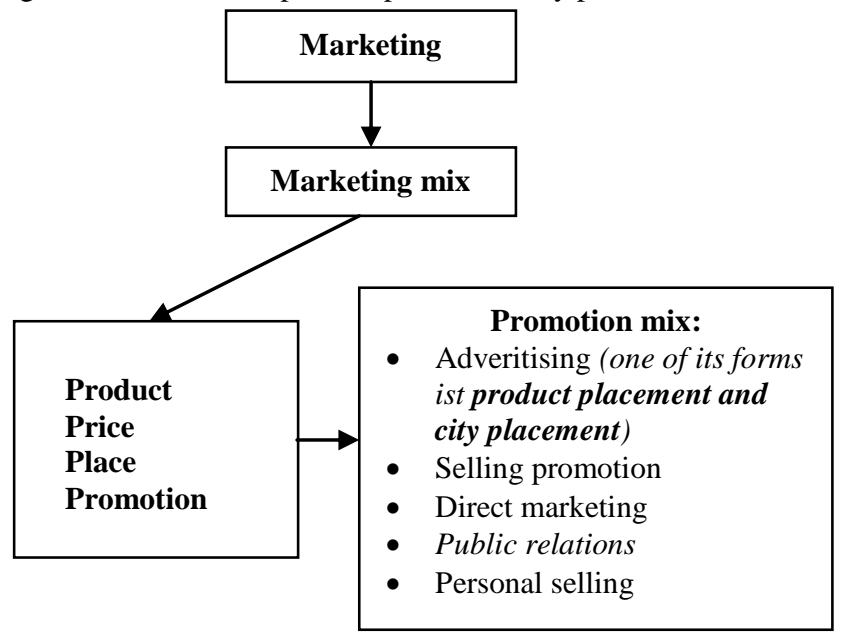

Source: own study

Avoiding open advertising affects the customer and fixed in his mind image of the brand. The advantage over traditional product placement advertising is to avoid zapping, or changing the TV channel. No wonder that more and more companies are opting for this form of advertising ${ }^{30}$. An example of product placement in US production is movie the Iron Man2. The main character Tony Stark drives an Audi R8 Spyder ${ }^{31}$.

\section{EXAMPLES OF CITY PLACEMENT}

Local and regional authorities use city placement to build the image of cities and promoting the city among potential tourists. Local governments establish contacts and thus sign a contract with the producers of films and TV series, then the film takes place in a particular municipality or county. A perfect example of such action is the Polish film "Father Matthew" placed in the picturesque Sandomierz. "Father Matthew" is Polish television series directed by Maciej Dejczer and Andrzej Kostenko produced since 2008 by Krzysztof Grabowski and Film Group Baltmedia for TVP. Father Matthew is a Polish version of a law enforcement-custom series Don Matteo. ${ }^{32}$.

Thanks to the film, Sandomierz has approx. $30 \%$ of the tourists more. To meet the needs of tourists the tourist route has been created. In the leaflet and on the website of Sandomierz you can find out in which places it was filmed and learn about the history of these places ${ }^{33}$.

\footnotetext{
${ }^{30} \mathrm{http} / / /$ www.egospodarka.pl/52549,Product-placement-po-polsku,1,20,2.html.

${ }^{31} \mathrm{http} / /$ productplacement.biz/201005113393/News/Product-Placement/product-placement-in-iron-man-2.html.

${ }^{32} \mathrm{http}: / / \mathrm{www}$. sandomierz.pl.

${ }^{33} \mathrm{http}: / /$ www.sandomierz.pl.
} 
The following figure 3 shows the first page of the leaflet, "In the Footsteps of Father Matthew".

Fig. 3. Leaflet of Sandomierz advertisement - following Father Mateusz

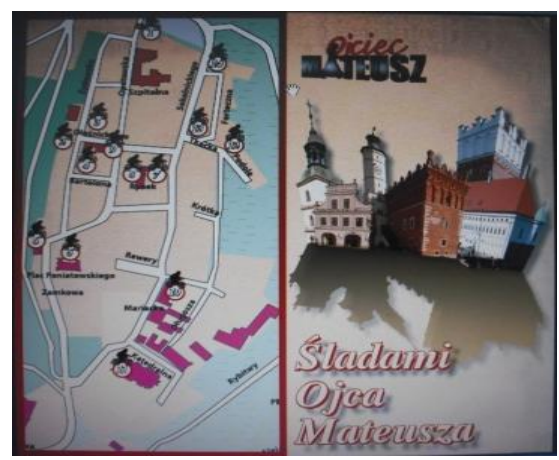

Source: www.sandomierz.pl (date of access: 15.06.2016)

Especially for the promotion the plot of the film was a bit changed. One character had a heart problem so they filmed his stay at Świętokrzyski Cardiology Center ${ }^{34}$.

Other examples, often unwittingly promoted, are the following: Wroclaw which is the scene of action "First Love", Jeruzal is Wilkowyje from the film "Ranch" in Złotopolice the action takes film "Złotopolscy", Okuniew is Tulchin from the "Vicarage", "Four Tank Men and a Dog" was placed near Tomaszów Mazowiecki.

Tourists choose to take trips to such places as New Zealand, where the "Lord of the Rings" was filmed or they also go to Oxford where action of the "Harry Potter" took place. As far as Poland is concerned there there was a campaign promoting Poland abroad. The action of some scenes of "The Chronicles of Narnia" took place around the Kamieńczyk Waterfall and the surrounding band of the Giant Mountains). The bollywood production the "Fanaa" took place in the Tatras (Tatras 'played' areas of Kashmir) ${ }^{35}$. The tourists - fans of the TV series "Rate larger than life" choose Gdansk, where they filmed episode of "Excelsior". In this stretch Kloss went on a trip to Gdansk, where he was to meet with Georg. On the set he was walking down the street Long Market, next to the Artus Court and the Neptune Fountain and the street St. Mary's. On the other hand, fans of the TV series "Alternative 4" could take a bus Ikarus city game, organized by the Institute Stefan Starzynski at the Warsaw Uprising Museum, called "In the Footsteps of Alternatives 4". Along the way, they read through a megaphone quiz questions. Final expedition took place in Ursynów, under the block Alternatives 4. The results were announced and awards were given ${ }^{36}$. There are also fans of the Mr Samochodzik travel route of the series of books by Zbigniew Nienacki. The plan of visit are the places where the series were filmed. "Mr Samochodzik" location: Malbork, Wiłkokuk and hut teacher Giby, Chwarszczany, the Lake Pomerania, Radzyń Chełmiński and Okonin near Grudzi-

\footnotetext{
${ }^{34}$ D. Malesa, Polska czaruje, "Newsweek Polska" 2010/22, p. 105.

${ }^{35}$ http://www.dziennik.pl/wydarzenia/article295956/Turysci_odwiedza_miasta_znane_z_seriali.html.

${ }^{36} \mathrm{http}: / /$ www.alternatywy4.net/gra-miejska-alternatywy4,1.html.
} 
adz ("Mr Samochodzik and the Templars"), Frombork ("Mr Samochodzik and the puzzles of Frombork") $)^{37}$.

The company PRESS-SERVICE Media Monitoring "analyzed the results of the presence of 11 place-names in the context of the 12 titles selected Polish TV series. The best position in terms of number of publications and potential contacts information from the recipient received Sandomierz, shown in the TV series "Father Matthew". City name was listed in 2012, nearly 900 times, and the range of publications stood at 550 million people. Torun - in which film "Doctors" was placed and Wrocław - "First Love" also crossed the dividing line 800 publications. With information about Torun had a chance encounter almost 450 million consumers. About less than 100 million fewer potential contacts was recorded in the capital of Lower Silesia - Wrocław. Further are the following: 650 - Łódź ("Commissioner Alex"), Lublin - 487 ("Everything before us") and Krakow ("Julia").

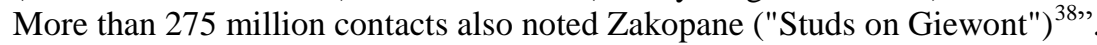

City placement turned out to be effective for Krakow ("Julia") and Ostróda ("On backwater") - nearly 81 percent Krakow also gained interest in connection with productions of "Detectives" (77 percent) and "W11 Investigation Division" (76 percent). The highlight of regional significance was the presence of Bydgoszcz in the series "Doctors" and "Law of Agatha". More than 71 percent communication on the participation of the city in the first production belonged to the regional media. In the case of series of legal percentage was nearly 64 percent. The regional media also frequently appeared about Łodz in the context of the "Commissioner Alex", Lublin ("Everything before us") and Drohiczyn ("Father Matthew").

As seen from the above analysis city placement is a very good form of advertising that encourages many local governments to use it. It is an opportunity to show the values of the location, the prestige of the town and attract tourists. The benchmarking exercise map shows the position of the individual towns media, taking into account three factors: the equivalent of advertising, reach and number information ${ }^{39}$. The following figure 4 shows media position of individual villages advertised in Polish films.

Offered tourist product which is the municipality space must be supported by marketing activities. Local governments increasingly see the need and necessity of communication with different groups of recipients of its activities and create such opportunities like city placement. The experience of Sandomierz in terms of city placement shows that it is worth investing in this form of promotion of the city. The increase in the number of tourists increase of cash flowing to municipalities and thus the development of the region.

\footnotetext{
${ }^{37}$ http://mia-ny.com/spacery/82-sladami-kobiet-z-seksu-w-wielkim-miescie.html.

${ }^{38} \mathrm{http} / / / \mathrm{www}$. epr.pl/city-placement-nowa-forma-promocji-polskich-miast,pr-w-mediach,37736,1.html.

${ }^{39} \mathrm{http}: / /$ www.epr.pl/city-placement-nowa-forma-promocji-polskich-miast,pr-w-mediach,37736,1.html.
} 
Fig. 4. Media position of individual villages advertised in Polish films: the equivalent of advertising, getting and the amount of information

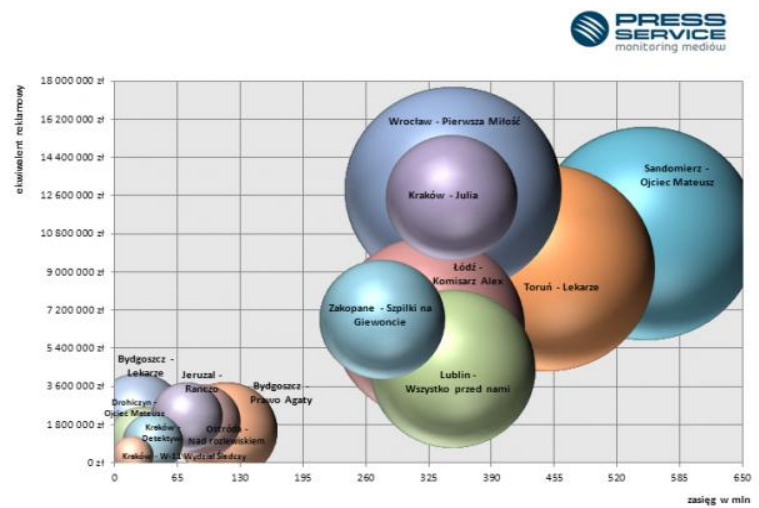

Source: http://www.epr.pl/city-placement-nowa-forma-promocji-polskich-miast,pr-wmediach,37736,1.html (date of access: 15.06.2016)

Territorial authorities can learn from the experiences of other cities in the Festival of Promotion of Cities and Regions. The project is aimed at local governments, public institutions, cultural centers, ministries, marketing agencies, media, experts and authorities in the field of promotion of cities. The organizer and initiator of the project is the Ströer Group in Poland, one of the leaders in the outdoor advertising market in Poland and Europe, present in 12 countries. Over the next four years created the largest in Poland and Europe recognized and prestigious event being a symbol of the integration of the local government, business and promote the highest standards of work, creativity, integrity and commitment in the process of image building and promotion of cities and regions ${ }^{40}$.

Given the fall in the efficiency of conventional advertising placement for city regions has become a popular form of promotion. City placement enables reaching the proper target market and the recipients of advertising certainly more likely to pay attention to alternative forms of building brand awareness and image of the region. Appropriate use of a set of instruments and marketing techniques in the management of promotion of the region is the basis of tourism development.

\section{BIBLIOGRAPHY}

[1] Chrzan E., Widawska-Stanisz A. Ponadregionalne znaczenie promocji zakładów przetwórstwa owocowo-warzywnego z Zielonego Wierzcholka Ślaska, [w:] Wybrane aspekty rozwoju regionalnego Polski południowej, ed. W. Ostasiewicz, P. Ucieklak-Jeż 37-51. Akademia Jana Długosza w Częstochowie 2008.

[2] Czarnecki A., Product placement. Niekonwencjonalny sposób promocji, PWE, Warszawa 2003.

[3] Klisiński J., Podstawy marketingu, Wyższa Szkoła Zarządzania w Częstochowie, Częstochowa 2001.

\footnotetext{
${ }^{40} \mathrm{http}: / /$ www.outdoordlamiast.pl/festiwal/ideafestiwalu.asp.
} 
[4] Knapik A., Składniki promocji mix oraz ich integracja, [w:] Środki i formy marketingowego oddziaływania na konsumentów, ed. A. Pabian, Wydawnictwo Politechniki Częstochowskiej, Częstochowa 2008, p. 152-165.

[5] Kotler P., Analiza, planowanie, wdrażanie i kontrola, Gebethner \&Ska, Warszawa 1994.

[6] Lazorko K., Wybrane aspekty komunikacji samorzadu terytorialnego z otoczeniem, "Zeszyty Naukowe Uniwersytetu Szczecińskiego" 473/2 (2007), p. 33-39.

[7] Malesa D., Polska czaruje, "Newsweek Polska" 2010/22.

[8] Marketing terytorialny: strategiczne wyzwania dla miast i regionów, ed. T. Domański, Uniwersytet Łódzki, Łódź 1997.

[9] Markowski T.,. Marketing Miasta, [w:] Marketing terytorialny, ed. T. Markowski, Komitet Przestrzennego Zagospodarowania Kraju PAN, Warszawa 2002.

[10] Organizacja imprez sportowych, ed. B. Ryba, Polska Korporacja Menedżerów Sportu w Warszawie 1998.

[11] Pabian A., Promocja. Nowoczesne środki i formy, Difin, Warszawa 2008.

[12] Przedsiębiorstwo Turystyczne. Ujęcie statyczne i dynamiczne, ed. G. Gołembski, PWE, Warszawa 2007.

[13] Sztucki T., Promocja. Sztuka pozyskiwania nabywców, Agencja Wydawnicza Placet, Warszawa 1995.

[14] Szromnik A., Marketing terytorialny - koncepcja ogólna i doświadczenia praktyczne, [w:] Marketing terytorialny, ed. T. Markowski, Komitet przestrzennego Zagospodarowania Kraju PAN, Warszawa 2006.

[15] Szromnik A., Marketing komunalny. Rynkowa koncepcja zarządzania gmina, "Samorząd Terytorialny" 1996/3, p. 3-19.

[16] http://www.epr.pl/city-placement-nowa-forma-promocji-polskich-miast,pr-wmediach,37736,1.html.

[17] http://www.wiadomosci24.pl/artykul/sladami_czterech_pancernych_w_zaganiu_98166.html.

[18] http://www.egospodarka.pl/52549,Product-placement-po-polsku,1,20,2.html.

[19] http://productplacement.biz/201005113393/News/Product-Placement/product-placement-iniron-man-2.html.

[20] http://www.sandomierz.pl.

[21] http://www.dziennik.pl/wydarzenia/article295956/Turysci_odwiedza_miasta_znane_z_seriali. $\mathrm{html}$.

[22] http://www.alternatywy4.net/gra-miejska-alternatywy4,1.html.

[23] http://mia-ny.com/spacery/82-sladami-kobiet-z-seksu-w-wielkim-miescie.html.

[24] http://nowewyrazy.uw.edu.pl/haslo/city-placement.html?pdf=1.

\section{PRODUCT PLACEMENT - CITY PLACEMENT JAKO FORMA PROMOCJI PRZESTRZENI MIEJSKIEJ}

W opracowaniu przedstawiono product placement, a dokładnie city placement, jako jedną z form promocji przestrzeni miejskiej bezpośrednio związaną z komunikacją z otoczeniem. Product placement jest już znaną formą promocji. Lokowanie produktu często pojawia się w filmach i serialach telewizyjnych. Zwiększa się zainteresowanie samorządów lokalnych tą formą reklamy - tym samym samorządy lokalne wydają więcej pieniędzy na city placement. Niewiele samorządów sprawdza efektywność city placement w porównaniu $\mathrm{z}$ reklamą tradycyjną. Wynika to z wysokich kosztów badań marketingowych.

City placement jest związane z promocją, ścile - z reklamą. Stwarza możliwość alternatywnej formy komunikowania się z otoczeniem. Przestrzeń miejską w niniejszym opracowaniu traktuje się jak produkt, który można sprzedać, ponieważ wszystko, co ma wartość dla konsumenta, może być oferowane w sprzedaży. Coraz więcej samorządów, współpracując z twórcami filmów i seriali, chce osiągnąć efekt porównywalny z tym, który osiągnął 
Sandomierz w czasie emisji serialu Ojciec Mateusz. Miasto, w którym toczy się akcja filmu, jest bohaterem danej produkcji, a nie tylko tłem rozgrywania się akcji w filmie.

Głównymi celami tego rodzaju reklamy są m.in. przyciągnięcie inwestorów, studentów, specjalistów, wzrost satysfakcji wśród mieszkańców oraz zmiana opinii na temat miasta. City placement to kreowanie wizerunku miasta. W niniejszym opracowaniu przedstawiono przykłady takiej formy prezentacji miasta lub gminy.

Slowa kluczowe: marketing, marketing terytorialny, komunikacja, promocja, reklama, product placement, city placement

\section{DOI: 10.7862/rz.2016.mmr.9}

Tekst złożono w redakcji: czerwiec 2016

Przyjęto do druku: czerwiec 2016 